\title{
Performance and adipose cellularity of female progeny of White Plymouth Rock dams and commercial broiler breeder sires
}

\author{
S.N. Nahashon', C.O. Briles, S.L. Louis and J.R. Bartlett \\ Department of Agricultural Sciences, \\ Tuskegee University. \\ Tuskegee, Alabama, USA
}

(Received 28 October 1999; accepted 8 May 2000)

\section{ABSTRACT}

The study was conducted to compare performance and abdominal adipose ccllularity in broilertype female progeny of commercial broiler breeder sires and White Plymouth Rock (WPR) dams, and in the WPR females. Nine hundred and eighty three WPR and 816 crossbred (CB) female progeny were fed diets containing $13 \mathrm{MJ} \mathrm{ME} / \mathrm{kg}^{-1}$ and $20 \% \mathrm{CP}$ ad libitum and body weight gain, feed intake and feed conversion, breast angle, carcass weight, abdominal fat weight and adipose cellularity werc determined at 58 days of age.

Body weight gain and feed intake were significantly higher $(\mathrm{P}<0.05)$ by 15.3 and $18 \%$, respectively, in the $\mathrm{CB}$ than in WPR progeny. Mean breast angie, carcass weight, abdominal fat weight and total lipid in abdominal fat pad were also $12,13.5,33$ and $42.8 \%$, respectively higher $(\mathrm{P}<0.05)$ in $\mathrm{CB}$ than WPR progeny. The CB progeny had significantly more fat cells of 230 to $290 \mu \mathrm{m}$ in diameter than WPR progeny $\left(0.31 \times 10^{7}\right.$ vs $\left.0.12 \times 10^{7}\right)$.

Negative and highly significant $(\mathrm{P}<0.01)$ correlations were observed between abdominal fat cell size and total fat cell number in abdominal fat tissue of WPR and CB progeny $(r=-0.89$ and -0.93 , respectively) suggesting that adipocyte hyperplasia and hypertrophy were contributing factors to adipose tissue growth. Although the CB progeny outperformed WPR progeny, they however accumulated more abdominal fat and total lipid and had more and larger adipocytes.

KEY WORDS: crossbreeding, performance, adipose cellularity, broiler, chickens

' Corresponding author, currently at: Department of Nutrition and Food Science, 328 Spidle Hall, Auburn University, Auburn, AL 36849-5605, USA 


\section{INTRODUCTION}

During the last few decades intensive genetic selection for the growth rate, aided by improved nutrition and management procedures has led to an increase in growth rate of broiler-type birds. Genetic selection has also resulted in large body size strains that grow rapidly. For instance, age requirement for broilers to attain $1.6 \mathrm{~kg}$ body weight in 1975 and 1985 was 49 and 37 days, respectively. Feed consumption per $\mathrm{kg}$ weight for the same two years was 2.0 and $1.75 \mathrm{~kg}$, respectively (Hartman, 1989). However, concomitant with the development of these desirable characteristics is increased abdominal fat deposition and altered body composition.

Excess carcass and abdominal fat in broilers is undesirable to the processor and consumer because it reduces meat quality. It accounts for about $10-15 \%$ of the liveweight in commercial broiler stock and this accounts for over 220 million $\mathrm{kg}$ per year. As a result, consumers and processors sustain a loss of approximately US\$ 250-300 million per year in pollution control, fat extraction and discarding excess carcass fat (Rosebrough and Steele, 1986).

Carcass fat composition may be modified by diet and genetic selection, but the extent of this alteration is variable and inconclusive, suggesting that other factors associated with adiposity may be involved. Most reports suggest that adipose tissue mass in poultry may be caused by either hyperplasia and/or hypertrophy of fat cells, however, the relationship between fat deposition and growth rate has not been fully assessed. According to Pfaff and Austic (1976), the contribution of cell size and number to the adiposity of White Leghorn chickens was similar to seven weeks of age, after which cellular hypertrophy was the more predominant factor. In contrast, March and Hansen (1977) observed that adipocyte size in White Leghorn chickens remained constant to six weeks of age and thus lipid accumulation to this age was primarily hypoplastic.

Using commercial broiler strain crosses, Hood (1982) reported that the number of adipocytes increases in the abdominal fat pad until 14 weeks of age and that this increase is proportional to growth rate. Cherry et al. (1984) reported that increased fat cell number is the major contributing factor to abdominal adipose tissue growth in broiler chickens prior to 28 days of age. However, results at older ages were inconclusive for differences among populations. According to Allen (1976), a relatively fixed percentage of adipocytes must reach a critical size $(1.2-1.6 \mu \mathrm{g}$ lipid cell $^{-1}$ ) before hyperplasia can be initiated in meat-type birds.

Since changes in adipose tissuc cellularity in relation to fat deposition in the chicken prior to sexual maturity are not clear and inconclusive, the objective of this study was to assess further adipocyte cellularity and associated quantitative traits of broiler-type female progeny of commercial broiler breeder sires and White Plymouth Rock dams. 


\section{MATERIAL AND METHODS}

\section{Mating scheme}

In two experimental replicates 20 sires and 80 dams of White Plymouth Rock (WPR) background and 20 commercial broiler breeder sires and 80 WPR dams were used for cage matings. Using standard techniques (North and Bcll, 1990), these birds were raised on floor pens and transferred into cages $(31.8 \mathrm{~cm}$ wide $\mathrm{x}$ $54 \mathrm{~cm}$ deep $\times 54 \mathrm{~cm}$ high) at 22 wecks of age.

Birds were artificially inseminated and semen from one male was used to inseminate 4 females. The artificial insemination was performed after every 4 days to ensure good fertility. Each hen received approximately $0.1 \mathrm{~mL}$ of semen which by use of hemocytometer counter was estimated to contain $8 \times 10^{8}$ (Yousif et al., 1984). Eggs were collected twice daily and stored in a cold room at a temperature of 10 to $15.5^{\circ} \mathrm{C}$ and a relative humidity of $60-80 \%$. Selected medium sized eggs were incubated for 21 days.

\section{Management}

Nine hundred and eighty three WPR and 816 crossbred (CB) female progeny were wing-banded for identification and vaccinated for Marek's discase at hatch. At 10 days of age, the chickens were vaccinated for Newcastle disease and infectious bronchitis intra-ocularly. These birds were raised to 58 days of age using standard brooding and rearing techniques (North and Bell, 1990). Feed was provided in mash form for ad libitum consumption and contained $20 \% \mathrm{CP}$ and $13 \mathrm{MJME} \mathrm{kg}^{-1}$ (Table 1). Feed intake was monitored daily throughout the study period whereas body weight gain, feed conversion ratios and breast angle were determined at 58 days of age.

Fat tissue harvesting

Approximately $10 \%$ of the total number of the female progeny from each treatment group were randomly selected and slaughtered on the 59th day. Prior to slaughter, these birds were starved for $15 \mathrm{~h}$. Incisions were made into the abdominal body cavity and abdominal fat, which consists of fat surrounding the gizzard, proventriculus and in abdominal body cavity, was immediately removed, weighed and $400-500 \mathrm{mg}$ samples frozen at $-20^{\circ} \mathrm{C}$ if not used immediately. Carcasses were weighed immediately after giblets and abdominal fat were removed. 
TABLE 1

Composition of experimental diet, \%

\begin{tabular}{lc}
\hline Ingredients & Composition \\
\hline Maize, yellow (8\% CP) & 57.40 \\
Soyabean meal (48\% CP) & 30.80 \\
Dehydrated lucerne meal (17\% CP) & 1.00 \\
Poultry fat & 6.38 \\
Dicalcium phosphate (18.5\% P. 24\% Ca) & 2.00 \\
Limestone (38\% Ca) & 1.10 \\
NaCl & 0.41 \\
Vitamin premix & 0.35 \\
Trace mineral premix & \\
DL-Methionine $(98 \%)^{4}$ & 0.19 \\
Coban 60 & 0.27 \\
Calculated & 0.10 \\
crude protein & \\
ME, MJkg-1 & 20 \\
\hline
\end{tabular}

" provided per kg of diet: retinyl acetate, 5775 IU; cholecalciferol, 1925 ICU; DL- $\alpha$-tocopheryl acetate, $1.93 \mathrm{IU}$; menadione sodium bisulfite complex. $0.96 \mathrm{mg}$; vitamin B , $9.6 \mathrm{mg}$; ribotlavin, $5.8 \mathrm{mg}$ : pantothenic acid, $9.6 \mathrm{mg}$; niacin, $38.5 \mathrm{mg}$; choline. $334 \mathrm{mg}$ : folic acid, $400 \mu \mathrm{g}$; ethoxyquin, $62.4 \mathrm{mg}$

" provided per kg of diet: manganese, $65 \mathrm{mg}$; iodine, $1 \mathrm{mg}$; iron, $54.8 \mathrm{mg}$; copper, $6 \mathrm{mg}$; zinc, $55 \mathrm{mg}$ : selenium, $0.3 \mathrm{mg}$

" Eli Lilly, Indianapolis, Indiana, USA

\section{Lipid extraction and determination of fat cell size and number}

Samples of abdominal adipose tissue ( $500 \mathrm{~g}$ ) from 58 day old birds were used for determination of adipocyte number and diameter according to the procedures described by Hirsch and Gallion (1968), Simon and Leclercq (1982) and Leclercq (1984). Bricfly, adipocyte tissue fragments were dissociated by collagenase treatment and total lipids were extracted in chloroform:methanol $(2: 1, \mathrm{v} / \mathrm{v})$ as described by Folch et al. (1957). Adipocytes were fixed in osmium tetroxide, filtered through nylon screens $(30,52,230$ and $290 \mu)$ and counted using a coulter counter at an aperture of $400 \mu$.

\section{Statistical analysis}

Percent data (abdominal fat and lipid in abdominal fat) were transformed to arc sine coefficients prior to analyses. The arc sine cocfficients were back transformed to percent data prior to tabulation of means. Data were subjected to analysis of variance using the GLM procedure of SAS (1990) with genotype as main effect. Least significant difference comparisons were made between treatment means for main 
effects when there was a significant F-value (Steele and Torrie, 1980). Correlation analyses among performance and abdominal fat parameters were computed using the GLM procedure. Significance implies $(\mathrm{P}<0.05)$ unless otherwise indicated.

\section{RESULTS AND DISCUSSION}

The means and standard crrors for performance traits of WPR and CB progeny are presented in Table 2 . The CB progeny outperformed the WPR progeny in most traits measured. Mean body weight gain, breast angle, and carcass weight were $15.3,12$, and $13.5 \%$, respectively higher $(\mathrm{P}<0.05)$ in the $\mathrm{CB}$ than WPR progeny. This may be attributed to superior genetic potential of the commercial broiler breeder males to increase growth rate, body weight gain and breast angle (Fairfull, 1990; Merat et al., 1994). The broiler breeder males were heavier at maturity ( 25 weeks of age) than the WPR males. These results support the premise that crossbreeding increases body weight and overall performance of broiler females as well as male progeny, but to a lesser extent (Briles et al.. 1988). The CB progeny had a higher percent of abdominal fat than WPR progeny as expected since abdominal fat is highly correlated with total body weight and fatness (Cahaner, 1988; Leclercq, 1988; Leenstra. 1988). Average daily feed intake was $18 \%$ higher in CB than WPR progeny. The higher feed intake of $\mathrm{CB}$ progeny is justified by their rapid growth rate and supported by reports of Pesti (1982) and Leeson et al. (1993) that birds adjust feed intake to meet their energy requirement for both growth and maintenance. Poor feed efficiency observed in fat lines may be a result of increased feed consumption and use of greater amount of consumed amino acids and energy for oxidation and lipogenesis. These findings were consistent with those of Sounderson and Whitehead (1987) and Whitehead and Sounderson (1988).

TABLE 2 Means and standard errors of quantitative traits for White Plymouth Rock and crossbred female progeny of White Plymouth Rock dams and commercial broiler brecder sires

\begin{tabular}{lccc}
\hline Traits & $\begin{array}{c}\text { White Plymouth } \\
\text { Rock }\end{array}$ & Crossbred & Pooled SEM \\
\hline Body weight gain, g/bird & & \\
Feed intake, g/bird $^{-1}$ day $^{-1}$ & $1631.90^{\mathrm{h}}$ & $1881.50^{\mathrm{a}}$ & 10.00 \\
Feed conversion ratio $^{\downarrow}$ & $63.60^{\mathrm{h}}$ & $74.80^{\mathrm{a}}$ & 2.40 \\
Breast angle. degrees $^{\mathrm{h}}$ & 2.22 & 2.29 & 0.11 \\
Carcass weight, g/bird $^{-1}$ & $13.50^{\mathrm{h}}$ & $15.10^{\mathrm{a}}$ & 0.30 \\
\hline
\end{tabular}

a.h means within rows with no common superscript differ significantly $(\mathrm{P} \leq 0.05)$

- standard error of means

$\checkmark$ gram of feed per gram of liveweigh gain 
The CB progeny had significantly higher mean abdominal fat weight and percent abdominal fat in adipose tissue than WPR progeny (60.4 vs $45.3 \mathrm{~g} / \mathrm{bird}$, and 3.2 vs $2.78 \%$, respectively) as expected (Table 3 ). However, differences in percent lipid in abdominal fat of $\mathrm{CB}$ and WPR progeny were not significant $(P>0.05)$. Genotype differences in response to dietary energy has been demonstrated by Shafey et al. (1990). The fact that the CB progeny had more abdominal fat than the WPR progeny may be because of the low response of dietary fat as opposed to the CB progeny. Karen-Zvi et al. (1990) observed similar results and suggested that lcan genotypes may show less response to dietary fat. It is also probably true that faster growing birds deposit more fat than their slow growing counterparts (Marks, 1990).

TABLE 3

Means and standard errors of abdominal fat parameters and cell count ${ }^{*}$ in White Plymouth Rock and crossbred female progeny of White Plymouth Rock dams and commercial broiler breeder sires

\begin{tabular}{lccc}
\hline & $\begin{array}{c}\text { White Plymouth } \\
\text { Rock }\end{array}$ & Crossbred & Pooled SEM" \\
\hline Traits & & & \\
abdominal fat weight, g/bird ${ }^{-1}$ & $45.3^{\mathrm{n}}$ & $60.4^{\mathrm{a}}$ & 3.2 \\
percent abdominal fat & $2.78^{\mathrm{h}}$ & $3.2^{\mathrm{a}}$ & 0.1 \\
lipid in abdominal fat, $\%$ & 53.0 & 58.2 & 2.9 \\
total lipid in fat pad, g/bird ${ }^{-1}$ & $25.0^{\mathrm{h}}$ & $35.7^{\mathrm{a}}$ & 2.2 \\
cells in abdominal fat, $\mathrm{x} 10^{7}$ & 5.6 & 7.7 & 1.2 \\
fat cell size & 0.5 & 0.5 & 0.1 \\
& & & \\
Cell size & & Count & \\
$<30$ & 2.31 & 2.36 & 0.30 \\
$31-52$ & 0.93 & 1.49 & 0.20 \\
$53-230$ & 2.20 & 3.57 & 0.80 \\
$230-290$ & $0.12^{\mathrm{b}}$ & $0.30^{\mathrm{a}}$ & 0.04 \\
\hline
\end{tabular}

a.b means within rows with no common superscript differ significantly $(\mathrm{P} \leq 0.05)$

( $\left(x 10^{7}\right)$

(3tandard error of means e-cell size expressed in microgram lipid per cell

, nicrometers

The heavier CB progeny exhibited $42.8 \%$ more total lipid, total cell number and larger cells in the abdominal fat tissue than the WPR progeny. The highest fat cell count was made from cells ranging from 53 to $230 \mu \mathrm{m}$ in diameter. Although differences in mean fat cell count in the CB and WPR progeny were not significant, CB progeny had significantly more fat cells of diameter ranging from 230 to $290 \mu \mathrm{m}$ than WPR progeny $\left(0.3 \times 10^{7} \mathrm{vs} 0.12 \times 10^{7}\right)$. These findings indicate that 
the CB progeny tend to have more cells, cells of larger size and even more abdominal fat than WPR progeny, an observation consistent with the report of Hood (1982) that prior to 14 weeks of age, the growth of the adipose tissue is primarily by adipocyte hypertrophy. These results also agree with the findings of Cherry et al. (1984) that increased fat cell number is the major contributing factor to abdominal adipose tissue growth in broiler chickens from 2 to 12 weeks of age then proceeded by adipocyte hypertrophy. According to our findings which also support the premise of Hood (1982) and Cherry et al. (1984), it is true that animals which become hyper-ccllular are prime candidates for obesity. There is also cvidence that, once attained, the number of constituent cells never decrease, and they tend to accumulate lipid in a normal rate (Robey et al., 1988). Faust et al. (1978) also suggested that the growth of adipose tissue is a result of a significant increase in adipocyte size, and that after a certain size is attained, continued depot enlargement is due to increased adipocyte number. These hypotheses are consistent with our findings since the fatter $(\mathrm{CB})$ progeny weighed more and had more abdominal fat as well as more fat cells than the lcaner birds (WPR). The large proportion of the variation in abdominal fat percentage could be, in most part, explained by adipocyte hypertrophy.

Correlation cocfficients among performance traits of WPR and CB progeny are presented in Table 4. Correlations between body weight and abdominal fat weight of $\mathrm{CB}$ progeny were positive and significant $(\mathrm{P}<0.05)$. Correlations between carcass weight, body weight and breast angle of both WPR and CB progeny were positive and highly significant $(\mathrm{P}<0.01)$. These findings agree with the data of Becker and Mirosh (1984) and Grunder et al. (1987) that the percent abdominal fat in broiler females increases with age. The positive correlations between abdominal fat weight and carcass weight suggests that, if selection is applied for reducing abdominal fat weight, a correlated response of lower liveweight may occur. This is, therefore, an indication that selection against abdominal fat weight in broilers while simultaneously selecting for increased body weight is difficult, since these

TABLE 4 Correlation coefficients among quantitative traits in Whitc Plymouth Rock and crossbred female progeny of White Plymouth Rock dams and commercial broiler breeder sires

\begin{tabular}{|c|c|c|c|c|c|c|}
\hline \multirow[b]{2}{*}{ Trail } & \multicolumn{3}{|c|}{ White Plymouth Rock progeny } & \multicolumn{3}{|c|}{ Crossbred progeny } \\
\hline & $\begin{array}{l}\text { breast } \\
\text { angle }\end{array}$ & $\begin{array}{l}\text { carcass } \\
\text { weight }\end{array}$ & $\begin{array}{l}\text { abdomina! } \\
\text { fat weight }\end{array}$ & $\begin{array}{l}\text { breast } \\
\text { angle }\end{array}$ & $\begin{array}{l}\text { carcass } \\
\text { weight }\end{array}$ & $\begin{array}{l}\text { abdominal } \\
\text { fat weight }\end{array}$ \\
\hline 58 day body weight & $0.32 *$ & $0.92 * *$ & 0.13 & $0.42 \%$ & $0.94^{* *}$ & $0.55^{*}$ \\
\hline Breast angle & & $0.62 * *$ & -0.15 & & $0.67^{* *}$ & 0.13 \\
\hline Carcass weight & & & 0.09 & & & $0.55^{*}$ \\
\hline
\end{tabular}

$*_{-} \mathrm{P}<0.05,{ }^{*}{ }_{-} \mathrm{P}<0.01$ 
two traits seem to be positively correlated. A method, other than selection, has to be devised to increase body weight while reducing the abdominal fat weight in broilers. Negative corrclations between abdominal fat weight and breast angle among the WPR birds provide evidence that selection for these traits may lead to a reduction of abdominal fat in broiler-type females.

Table 5 presents correlation coefficients of abdominal fat parameters of WPR and $\mathrm{CB}$ progeny. Negative and highly significant $(\mathrm{P}<0.01)$ correlations were observed between abdominal fat cell size and total fat cell number in abdominal fat

TABLE 5

Correlation coefficients among abdominal tat parameters in White Plymouth Rock and crossbred female progeny of White Plymouth Rock dams and commercial broiler breeder sires

\begin{tabular}{|c|c|c|c|c|c|c|c|c|}
\hline \multirow[b]{2}{*}{ Traits } & \multicolumn{4}{|c|}{ White Plymouth Rock progeny } & \multicolumn{4}{|c|}{ Crossbred progeny } \\
\hline & $\begin{array}{l}\text { percent } \\
\text { lipid }\end{array}$ & $\begin{array}{l}\text { lipid } \\
\text { in } \mathrm{AF}^{\mathrm{a}}\end{array}$ & $\begin{array}{l}\text { cclls } \\
\text { in AF }\end{array}$ & $\begin{array}{l}\text { cell } \\
\text { size }\end{array}$ & $\begin{array}{l}\text { percent } \\
\text { lipid }\end{array}$ & $\begin{array}{l}\text { lipid } \\
\text { in AF }\end{array}$ & $\begin{array}{l}\text { cells } \\
\text { in AF }\end{array}$ & $\begin{array}{l}\text { cell } \\
\text { size }\end{array}$ \\
\hline Abdominal fat weight & -0.38 & $0.75^{* *}$ & $0.79 * *$ & $-0.75 * *$ & -0.41 & $0.65^{*}$ & -0.02 & -0.04 \\
\hline Percent lipid in AF & & 0.32 & 0.01 & 0.38 & & 0.42 & $0.83 * *$ & $-0.61^{*}$ \\
\hline Total lipid in AF & & & $0.85^{* *}$ & $-0.54 *$ & & & $0.66^{*}$ & $-0.53^{*}$ \\
\hline Cells in $\mathrm{AF}$ & & & & $-0.89 * *$ & & & & $-0.93 * *$ \\
\hline
\end{tabular}

" abdominal fal * $-\mathrm{P}<0.05, * *-\mathrm{P}<0.01$

tissue in the WPR and CB progeny $(r=-0.89$, and -0.93 , respectively). Total lipids in abdominal fat and number of fat cclls in the fat tissues were also negatively correlated with fat cell size. Previous reports (Pfaff and Austic, 1976) that support this observation indicated that the growth of the adipose tissue in broiler-type chickens is strictly controlled by adipose hypertrophy and hyperplasia. Therefore, controlling fat cell size and number, while increasing liveweight gain of broilers may be an effective way to reduce the size of the abdominal and carcass fat tissuc of broiler-type birds. The negative correlation between abdominal fat cell size and fat cell number is an indication that the growth of the abdominal fat tissue is either influenced by fat cell number or fat cell size. This may be the reason why there were fewer large fat cells (231-290 $\mu \mathrm{g})$ because, according to Allen (1976), a relatively fixed percentage of adipocytes must reach a critical size (1.2-1.6 $\mu \mathrm{g}$ lipid cell ${ }^{-1}$ ) before hyperplasia can be initiated in meat-type birds. The mean adipocyte size ( $\mu$ g lipid cell ${ }^{-1}$ ) for $\mathrm{CB}$ and WPR progeny were 0.53 and 0.50 , respectively. Since adipocyte hypertrophy is a function of time, more time is required beyond the 58 days of our study to allow initiation of adipocyte hypertrophy in these broiler-type females, although at older ages most reports tend to be inconclusive (Cherry et al., 1984). 


\section{CONCLUSIONS}

Based on this study, body weight, feed intake, breast angle and carcass and abdominal fat weight of CB progeny were larger than those of WPR progeny. Likewise, CB progeny which accumulated more abdominal fat and total lipid had more and larger adipocytes than WPR progeny suggesting that adipocyte hyperplasia and hypertrophy were contributing factors to adipose tissue growth. Positive correlations between body weight gain and abdominal fat deposition were observed, however, differences in percent lipid in abdominal fat tissuc were not significant.

\section{REFERENCES}

Allen C.E., 1976. Cellularity of adipose tissue in meat animals. Fed. Proc. 35, 2302-2307

Becker W.A., Mirosh L. W. 1984. Abdominal fat in broiler breeders. Poultry Sci. 63, 819-821

Briles C.O.. Lawrence L., Tivzenda P.T.. 1988. Effects of dietary energy on economical traits of selected broiler-type cockerels. Poultry Sci. 67, Suppl. 1, 6 (Abstr.)

Cahaner A.. 1988. Leanness in Domestic Birds. B. Leclercq, C.C. Whitehead (Editors). Butterworths. London, pp. 71-86

Cherry J.A., Swartworth W.J., Siegel P.B., 1984. Adipose cellularity studies in commercial broiler chicks. Poultry Sci. 63, 97-108

Fairfull R.W., 1990. Heterosis. In: R.D. Crawford (Editor). Poultry Breeding and Genetics. Elsevier, Amsterdam (The Netherlands), pp. 913-933

Faust I. M., Johnson P.R.. Stern J.S.. Hirsch J., 1978. Diet-induced adipocyte number increase in adult rats. A ncw model of obesity. Amer. J. Physiol. 235, E279-E286

Folch J., Lees M., Stanley G.H.S., 1957. A simple method for the isolation and purification of total lipids from animal tissues. J. Biol. Chem. 226, 497-509

Grunder A.A., Chambers J.R., Fortin. A., 1987. Plasma very low density lipoprotein, abdominal fat lipase and fatness during rearing in two strains of broiler chickens. Poultry Sci. 66, 471-479

Hartman W. 1989. From Mendel to multinational in poultry breeding. World Poultry Sci. J. 45, 5-9

Hirsch J., Gallion E., 1968. Methods for the determination of adipose cell size and cell number in man and animals. J. Lipid Res. 9, 110-119

Hood R.L., 1982. The cellular basis for growth of the abdominal fat pad in broiler-type chickens. Poultry Sci. 61, 117-121.

Karen-Zvi S., Nir I., Nitsan Z., Cahaner A., 1990. Effect of dietary energy concentration of fat and energy of fat deposition in broilers divergently selected for high of low abdominal adipose tissuc. Brit. Poultry Sci. 31, 507-516

Leclercq B., 1984. Adipose tissue metabolism and its control in birds. Poultry Sci. 63, 2044-2054

Leclercq B., 1988. Leanness in Domestic Birds. B. Leclercq, C.C. Whitchead (Editors). Butterworths. London, pp. 25-40

Leenstra F.R.. 1988. Leanness in Domestic Birds. B. Leclercq, C.C. Whitehead (Editors). Butterworth, London, pp. 59-69

Leeson S.. Summers J.D., Caston L., 1993. Growth response of immature brown-egg strain pullets to varying nutrient density and lysine. Poultry Sci. 72, 1349-1358 
March B.E., Hansen G., 1977. Lipid accumulation and cell multiplication in adipose bodies in White Leghorn and brotler-type chickens. Poultry Sci. 56, 886-894

Marks H.L., 1990. Genotype by diet interactions in body and abdominal fat weight in broilers. Poultry Sci, 69, 879-886

Merat P.. Minvielle F., Bordas A., Coquerelle G., 1994. Heterosis in normal versus dwarf laying hens. Poultry Sci. 73,1-6

North M.O., Bell D.D. (Editors). 1990. Commercial Chicken Production Manual. 4th Edition. AVI Publishing Co. Van Nostrand, Reinhold, New York, NY

Pesti G.M., 1982. Characterization of the response of male broiler chickens to diets of various protein and energy contents. Brit. Poultry Sci. 23, 527-537

Pfaff F.E. Jr., Austic R.E., 1976. Influence of diet on the development of the abdominat tat pad in the pullet. J. Nutr. 106, 443-450

Rosebrough R.W., Stcele N.C., 1982. The role of carbohydrates and protein level in the regulation of lipogenesis in the turkey poult. Poultry Sci, 61, 2212-2217

Robey W.W., Cherry J.A., Siegel P.B., Van Krey H.P., 1988. Hyperplastic response of adipose tissue to caloric over consumption in sexually mature chickens. Poultry Sci. 67, 800-808

SAS., 1990. SAS/STAT Users Guide. Release 6.03 Edition. SAS Institute, Inc. Cary, NC

Shafey T.M., McDonald M.W., Pym R.A.E., 1990. The effect of dictary calcium upon growth rates. food utilization and plasma constituents in lines of chickens selected for aspects of growth or body composition. Brit. Poultry Sci. 31, 577-586

Simon J.. Leclercq B., 1982. Longitudinal study of adiposity in chickens selected for high or low abdominal fat content: further evidence of a glucose-insulin imbalance in the fat line. J. Nutr. 112. $1961-1973$

Sounderson C.L., Whitehead C.C., 1987. N-methyl histidine excretion and [ $\left.\mathrm{U}^{14}-\mathrm{C}\right]$ amino acid oxidation in fully fed chickens from two lines selected for high and low body fat contents. Comp. Biochem. Physiot. 86B, 419-422

Steele R.G.D., Torrie J.H. (Editors), 1980. Principles and Procedures of Statistics. McGraw-Hill Book Company Inc., New York, NY

Whitchead C.C., Sounderson C.L., 1988. Body composition and carbon dioxide production and lipogenesis from $\left[\mathrm{U}-{ }^{14} \mathrm{C}\right]$ amino acids in pair-fed broiler chickens from two lines of chickens selected from high and low body fat content. Comp. Biochem. Physiol. 89B, 127-129

Yousif Y.F., Ansaband G.A., Buckland R.B., 1984. Effect of selection for fertility of frozen-thawed semen in chickens on the fertility of fresh and stored semen. Poultry Sci. 63. 1475-1480 


\section{STRESZCZENIE}

Wyniki produkcyjne oraz liczba i wielkość komórek tluszczowych u żeńskiego potomstwa kurek White Plymouth Rock i kogutów z komercyjnej linii męskiej brojlerów

W pracy porównano wyniki produkcyjne oraz liczbę i wielkość komórek tłuszczowych u kurek White Plymouth Rock (WPR) i żeńskiego potomstwa samic WPR i samców z komercyjnej linii brojlerów. 983 kurki WPR i 816 kurek mieszańców (CB) żywiono do woli dietami o zawartości $13 \mathrm{MJ} \mathrm{ME} / \mathrm{kg}^{-1}$ i $20 \%$ białka. W 58 dniu życia mierzono przyrost masy ciała, pobranie i wykorzystanie paszy, kąt picrsi, masę tuszki, masę oraz liczbę i wielkość komórek tłuszczowych w thuszczu brzusznym.

Przyrost masy ciała i pobranie paszy było istotnie większe ( $\mathrm{P}<0,05)$, odpowiednio o 15,3 i $18 \%$ u kurek CB niż WPR. Średnia wielkość kąta piersi, masa tuszki, masa i całkowita zawartość lipidów w tłuszczu sadełkowym były równicż o $12 ; 13,5 ; 33$ i 42,8\% większe $(\mathrm{P}<0.05)$ u kurek CB niż WPR. Kurki CB miały istotnie więcej najcieńszych komórek tłuszczowych o średnicy od 230 do $290 \mu \mathrm{m}$ niż kurki WPR $\left(0.3 ! \times 10^{7}\right.$ vs $\left.0,12 \times 10^{7}\right)$.

Wysoce istotna ujemna korelacja $(\mathrm{P}<0,01)$ między wiclkością j liczbą komórek tłuszczowych w thuszczu sadełkowym u kurek WPR i CB $(\mathrm{r}=-0,89 \mathrm{i}-0,93)$ wskazuje. że zarówno hiperplazja jak i hipertrofia przyczyniają się do przyrostu tkanki tłuszczowej.

Chociaż wyniki produkcyjne kurek CB były lepsze niż WPR, to jednak odkładały one więcej tłuszczu brzusznego i lipidów, a ich komórki tłuszczowe były większe. 